\title{
Synthesis and pharmacological evaluation of guanidinederivatives with potential hypoglycemic activity
}

\author{
Patrícia de Albuquerque Sarmento ${ }^{*}$, Polliane Maria Cavalcante-Araújo ${ }^{2}$, Igor Santana de Melo², \\ Paulo Henrique Barcellos França', Návylla Candeia de Medeiros², Tales Lyra de Oliveira², Thaís Honório Lins ${ }^{3}$, \\ Regina Célia Sales Santos Veríssimo³, Maria Lysete de Assis Bastos³, Êurica Adélia Nogueira Ribeiro1, \\ Robinson Sabino-Silva², João Xavier de Araújo-Júnior ${ }^{1}$
}

From 5th Congress of the Brazilian Biotechnology Society (SBBIOTEC)

Florianópolis, Brazil. 10-14 November 2013

\section{Background}

The hyperglycemia characteristic of diabetes can cause cellular and tissue damage due to the biochemical alterations that lead to the formation and accumulation of advanced glycation end products (AGEs) [1]. Aminoguanidine (AG) prevents the formation of AGEs by reacting with the initial glycation products, proving to be effective in improving proteinuria and vessel elasticity, in the prevention of diabetic retinopathy, and in the treatment of patients with diabetic nephropathy [2]. Guanidine derivatives have demonstrated various biological activities, such as antihypertensive and antidiabetic effects. It has been proposed that aminoguanidine and some of its derivatives (DAGs) may increase sensitivity to insulin [3]. The aims of this study were to investigate the effect of AG and two of its derivatives (DAG11 and DAG15) on the regulation of blood glucose and on the insulin tolerance test (ITT) in normoglycemic and diabetic rats, and the possible toxic effects of these derivatives.

\section{Method}

Wistar rats, 2 months of age, which had diabetes induced by Alloxan $(40 \mathrm{mg} / \mathrm{kg}$, i.v.), and their controls were administered the vehicle. At 21 days after the induction of diabetes, the animals were intraperitoneally treated for 7 consecutive days with saline (SAL), AG $(10 \mathrm{mg} / \mathrm{kg})$, DAG11 or DAG15 $(10 \mathrm{mg} / \mathrm{kg})$. On the 28 th day the animals were anesthetized (ketamine, $80 \mathrm{mg} / \mathrm{kg}$ and xylazine,

'Laboratório de Pesquisa em Recursos Naturais, Universidade Federal de

Alagoas, Maceió, Brazil

Full list of author information is available at the end of the article
$12 \mathrm{mg} / \mathrm{kg}$ ) and the ITT was performed with the administration of insulin $(0.75 \mathrm{UI} / \mathrm{kg}$, i.v.) for the analysis of insulin sensitivity through the glucose decay constant (klTT). The results were expressed as mean \pm SEM and were compared using ANOVA, with Student-Newman-Keuls post hoc test $(\mathrm{p} \leq 0.05)$. The toxicological evaluation was performed using human lymphocytes[4]. The study was approved by the Ethics Committee for the use of animals of the Federal University of Alagoas UFAL: 01/2012.

\section{Results and conclusions}

The basal blood glucose of the animals treated with SAL, AG, DAG11 and DAG15 presented no significant differences. In the normoglycemic animals, although no significant difference occurred between the experimental groups, there was an increase of $55 \%$ and $67 \%$ in the kITT of the AG and DAG15 rats, respectively, compared to the SAL animals. The diabetic animals treated with AG and DAG15 presented increased $(\mathrm{p} \leq 0.05)$ kITT $(150 \%$ and $81 \%)$ compared to the SAL animals. No toxic effects were observed for any of the substances tested, at least not in the model used. Despite having no action on basal glucose, AG and DAG15 may be promising prototypes for diabetes treatment drugs, in view of their increased insulin sensitivity action in diabetic animals.

\section{Acknowledgements}

National Council for Scientific and Technological Development (CNPq Grant No. 563660/2010-4) 


\section{Authors' details}

'Laboratório de Pesquisa em Recursos Naturais, Universidade Federal de Alagoas, Maceió, Brazil. 'Laboratório de Neurociências e Fisiologia Integrativa, Universidade Federal de Alagoas, Maceió, Brazil. ${ }^{3}$ Laboratório de Pesquisa e

Tratamento de Feridas, Universidade Federal de Alagoas, Maceió, Brazil.

Published: 1 October 2014

\section{References}

1. Kontogianni VG, Charisiadis P, Margianni E, Lamari FN, Gerothanassis IP, Tzakos AG: Olive leaf extracts are a natural source of advanced glycation end product inhibitors. J Med Food 2013, 16(9):817-22, doi:10.1089/ jmf.2013.0016.

2. Carvalho VF, Florim LT, de O Barreto E, Torres RC, Batista MM, Amendoeira FC, Cordeiro RS, Martins MA, E Silva PM: Inhibition of advanced glycation end products by aminoguanidine restores mast cell numbers and reactivity in alloxan-diabetic rats. European Journal of Pharmacology 2011, 669:143-148, doi:10.1016/j.ejphar.2011.08.004.

3. Larsen SD, Connell MA, Cudahy MM, Evans BR, Maio PD, Meglasson MD, O'Sullivan TJ, Schostarez HJ, Sih JC, Stevens FC, Tanis SP, Tegley CM, Tucker JA, Vaillancourt VA, Vidmar TJ, Watt W, Yu JH: Synthesis and Biological Activity of Analogues of the Antidiabetic/Antiobesity Agent 3Guanidinopropionic Acid: Discovery of a Novel Aminoguanidinoacetic Acid Antidiabetic. J Med Chem 2001, 44(8):1217-30, doi: 10.1021/jm000095f.

4. Mahomoodally FM, Subratty AH, Gurib-Fakim A, MI Choudhary MI: Antioxidant, antiglycation and cytotoxicity evaluation of selected medicinal plants of the Mascarene Islands. BMC Complementary and Alternative Medicine 2012, 12:165, doi:10.1186/1472-6882-12-165.

doi:10.1186/1753-6561-8-S4-P10

Cite this article as: Sarmento et al: Synthesis and pharmacological evaluation of guanidinederivatives with potential hypoglycemic activity. BMC Proceedings 2014 8(Suppl 4):P10.

\section{Submit your next manuscript to BioMed Central and take full advantage of:}

- Convenient online submission

- Thorough peer review

- No space constraints or color figure charges

- Immediate publication on acceptance

- Inclusion in PubMed, CAS, Scopus and Google Scholar

- Research which is freely available for redistribution

Submit your manuscript at www.biomedcentral.com/submit 